\title{
ИССЛЕДОВАНИЕ МЕЖКУЛЬТУРНОГО КОНФЛИКТА В КИТАЙСКО-РОССИЙСКИХ ТРАНСНАЦИОНАЛЬНЫХ БРАКАХ ${ }^{1}$
}

\section{RESEARCH ON THE CROSS-CULTURAL CONFLICT IN SINO-RUSSIAN TRANSNATIONAL MARRIAGE}

Jiang Dan

Summary: In recent years, the number of transnational marriages has been increasing, especially in border areas. The advantages of geographical factors, the development of tourism, the promotion of academic exchanges and the friendly relations between the neighboring two countries have made the residents of the two countries closer. Although Sino-Russian transnational marriages are not contemporary mainstream marriages, the stability of their marriages continues to increase and the speed of development continues to increase, which not only deepens the friendly exchanges between the two countries, but also enables further cultural exchanges between the two countries. However, with the development of economy and the deepening of global integration, the phenomenon of transnational marriages makes crosscultural conflicts in transnational marriages unavoidable.

Keywords: China and Russia, transnational marriage, cross-cultural conflict.

\section{Введение}

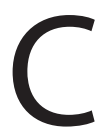
развитием глобализации количество транснациональных браков и отношений между жителями соседних стран стало увеличиваться в современном мире. Этому способствует дружественное развитие китайско-российских отношений, что оказало влияние на увеличение китайско-российских транснациональных браков. Глобализация культуры также стала причиной роста китайско-российских транснациональных браков и любви между супругами разных национальностей. Транснациональный брак определяется как брачные отношения, выходящие за пределы национальных границ и между людьми из разных стран. Однако из-за наличия культурных различий китайско-российские транснациональные браки имеют культурные конфликты, которых нет в обычных внутриэтнических браках. Китайско-российские транснациональные супруги развивают свои отношения, поддерживают свой брак, обретают счастье,

\author{
Цзян Дань \\ Аспирант, Забайкальский государственный \\ университет; дочент, Хэйхэский университет Китая \\ waiyuxijiangdan@163.com
}

Аннотация: В последние годы наблюдается тенденция к увеличению числа транснациональных браков, особенно на приграничных территориях. Преимущественно географические факторы, развитие туризма, содействие академическим обменам и дружеские отношения между двумя соседними странами сделали жителей России и Китая ближе. Хотя китайско-российские транснациональные браки не являются современными обычными браками, их численность продолжает расти, что не только углубляет дружеские обмены между двумя странами, но и способствует дальнейшему культурному обмену между ними. Однако с развитием экономики и углублением глобальной интеграции феномен транснациональных браков делает неизбежными межкультурные конфликты в транснациональных браках.

Ключевые слова: Китай и Россия, транснациональный брак, межкультурный конфликт.

поскольку культурная адаптация стала единственным способом развития китайско-российских транснациональных супругов.

Китайско-российский транснациональный брак и любовь - это практическая область культурной адаптации. Успешная культурная адаптация способствовала счастливому и благоприятному российско-китайскому транснациональному браку и любви. Неудачная культурная адаптация вызывает несчастья и трагедию. В результате в китайско-российских транснациональных браках по любви выявлены культурные конфликты и проблемы адаптации. Кроме того, культурная адаптация является важным фактором межкультурного общения.

Исследование и обсуждение проблемы культурной адаптации способствует развитию исследований межкультурной коммуникации, а также дополнению исследований социологии.

1 Данная статья публикуется в рамках научно-исследовательского проекта основного операционного расхода вузов в провинции Хэйлунцзян 2018 г. на тему «Изучение изменений истории и нынешнего состояния китайских мигрантов на фоне районов в России». Проект:2018-KYYWF-1283. 
І. Причины межкууьтурных конфликтов в китайско-российских транснашиональных браках

\section{1. Исторические причины формирования межкультурных конфликтов в китайско-российских транснашиональных Браках}

Китай и Россия всегда были дружественными странами, сохраняющими отношения сотрудничества. В связи с постоянным углублением политических, экономических, торговых и личных обменов между двумя странами, некоторые мероприятия, такие как «Год страны», значительно способствовали развитию и обогащению друг друга, взаимопониманию между народами двух стран и традиционной дружбе между странами. В последние годы между Китаем и Россией становится все больше транснациональных браков.

Отметим, что китайско-российские транснациональные браки имеют давнюю историю. До «Октябрьской революции» в России в 1917 году значительное количество китайцев уезжало в Россию работать шахтерами. После «Октябрьской революции» большое количество россиян перебралось на китайскую границу, чтобы поселиться в Китай. Количество транснациональных браков резко возросло. После реформы и открытости, хотя китайско-российские транснациональные браки подвергались определенным юридическим ограничениям, они все еще растут [2, с. 133].

С конца XIX до начала XX века китайско-российские транснациональные браки набирали популярность. Большое количество китайских рабочих и китайских бизнесменов познакомились с русскими женщинами на производстве, в труде и в жизни, и у них возникла взаимная привязанность. Русскими женщинами приветствовались такие хорошие качества китайских мужчин, как трудолюбие, прагматичность, сильное чувство ответственности и холодное отношение к алкоголю. Многие китайцы часто женятся на русских женщинах. В этот период количество китайско-российских браков продолжало расти, увеличивая количество зарубежных китайских браков в Амурской и Приморской областях.

В соответствии с российским законодательством китайцы, живущие за границей, должны официально присоединиться к Православной церкви и пройти формальное крещение в церкви, прежде чем они смогут вступить в брак со здоровой россиянкой. Только вступив в брак с русской женщиной, китайцы за границей могут получить право на законное проживание в России и единственный способ получить российское гражданство. Многие китайцы, живущие в России, не могут отказаться от традиционной китайской культуры и жениться на местной русской женщине. Это ограничивается добровольным фактическим браком и не может быть защищено законом. По статистике между Китаем и Россией в деревнях вдоль реки Эргун было 33 таких смешанных брака. Российские местные власти осторожно относятся к смешанным бракам между Россией и Китаем. Потому что многие китайцы молодого и среднего возраста за границей уже вступили в брак в своих родных городах, а их жены заботятся о своих родителях и детях дома. Такие мужчины на русских женщинах женятся второй раз, имея первую законную супругу в Китае [3, с. 313]. Если русская женщина не поедет за мужем обратно в деревню после замужества, ее бросят. Согласно российскому законодательству, если русская женщина вступает в брак с китайцем и не может продолжать жить в России, русские женщины и их дети, которые поселяются в Китае, автоматически теряют свое российское гражданство. Многие русские женщины не могут покинуть свои семьи, поэтому они отказываются от российского гражданства и возвращаются в страну вместе со своими мужьями.

В течение 1920-х и 1950-х годов из-за политических факторов количество смешанных браков между Китаем и Россией увеличилось. Из-за особого географического положения в приграничной зоне Китая и России проживает множество смешанных семей из Китая и России, которые образуют уникальные русские деревни, способствуя развитию интеграции еды, языка, одежды, культуры и других аспектов жителей приграничных территорий Китая и России. Российские ученые считают, что правительство Китая активно продвигает и решительно поддерживает смешанные браки между Россией и Китаем с целью ассимиляции русской нации. Соседи на Дальнем Востоке используют форму транснационального брака для интеграции. Кристаллизация этого смешанного брака - китайские и русские дети смешанной расы получают образование в условиях слияния двух разных культур, поэтому существуют определенные межкультурные коммуникативные барьеры. Что касается будущего роста детей, существует определенная проблема разделения сознания «этой нации» и «другой нации», что является первопричиной межкультурных конфликтов между китайско-российскими транснациональными браками.

\section{2. Сознательные причины формирования межкультурных конфликтов в китайско- российских транснациональных Браках}

У.Б. Гудикунст, специалист по межкультурным коммуникациям, считает, что культурное измерение индивидуализма и коллективизма обеспечивает мощную основу для лучшего понимания культурных различий в личном общении. Этот уровень незаменим, особенно когда речь 
идет о культурных различиях. Ценностная ориентация индивидуализма и коллективизма может отражаться в нашей повседневной жизни, в школах, офисах и семьях. Следовательно, в межкультурном браке основными переменными факторами являются индивидуализм и коллективизм. Он провел много исследований своих ученых [4, с. 87].

Триандис считает, что индивидуализм и коллективизм являются наиболее важными факторами, различающими культуры. В культуре индивидуализма люди склонны заботиться о себе и своих семьях, отстаивают независимость, конфиденциальность и сосредотачиваются на себе. Напротив, в коллективистской культуре люди несут ответственность и обязательства перед группой, что превышает значение власти, и люди всецело зависят от организации. Функции коллективизма и индивидуализма воплощены в стиле общения высокого и низкого контекста. Характеристики высокого контекста - эвфемизм, расплывчатость, размышление и молчание. Характеристики низкоконтекстного общения: прямые, ясные, открытые и точные. Первый подходит для коллективистской культуры, а второй - для индивидуалистической культуры. В китайско-российских транснациональных браках влияние высокого и низкого контекста относительно велико. Это влияние в основном отражается в различных способах выражения и даже мышления. Для России, которая привыкла использовать четкую информацию, непросто понять значение китайских выражений [5, с. 54]. Из-за разницы в самовыражении в многонациональных браках часто возникают небольшие разногласия.

Внутреннее различие в групповом сознании также является причиной конфликтов и разногласий. Так называемая внутренняя группа относится к группе, которая важна для человека. В индивидуалистической культуре у людей есть много определенных внутренних групп, таких как социальные клубы, религиозные организации, семьи, профессиональные организации и т.д. В коллективизме не так много внутренних групп, принадлежащих отдельным лицам, таких как рабочие единицы, семьи, школы и т.д. Таким образом, из-за многочисленности внутригрупповых отношений в индивидуализме их влияние на индивидов относительно слабо, а в культуре коллективизма влияние внутригрупповых явлений относительно невелико. В китайско-российских транснациональных браках влияние внутригруппового сознания может проявляться в двух аспектах. С одной стороны, это влияние общества на транснациональные браки, особенно в Китае. Китайцы уделяют большое внимание группам, в которых они принимают участие. Вся страна представляет собой группу, обычно очень «чужую», и рассматривает Россию как аутсайдера или даже злоумышленника. Поэтому некоторые китайские и российские транснаци- ональные браки покидают эту среду, чтобы сохранить свои браки. С другой стороны, в китайско-российских транснациональных браках русские рассматривают жен и мужей как внутреннюю группу, в то время как китайцы думают, что члены семьи и родственники их партнеров все находятся в одной внутренней группе, так что «один человек получает выгоду, праведность». Пословица« Курица и собака восходят на небо». Различное сознание внутри группы в определенной степени повлияло на китайско-российские транснациональные браки.

\section{II. Межкультурные конфликты в китайско-российских межкультурных браках}

\section{1. Конфликт культуры языка}

Язык является основным выражением человеческой культуры. Языковое общение позволяет понимать друг друга. Напротив, языковые различия также могут стать причиной конфликтов. Следовательно, язык склонен вызывать противоречия в жизни китайско-российских транснациональных браков. Неспособность общаться на языке своего партнера будет мешать проявлению чувств и эмоций, пониманию и принятию своего партнера. Непонимание языка супруга в китайско-российском транснациональном браке является частой причиной конфликтов [1, с. 155]. Пары с высоким уровнем образования в китайско-российском транснациональном браке могут общаться более эффективно, чем пары с более низким уровнем образования. Таким образом, пары с высоким уровнем образования имеют меньше конфликтов при языковой адаптации и могут понимать друг друга. Для пар в китайско-российских транснациональных браках, когда есть языковой и культурный барьер, обе стороны должны медленно адаптироваться друг к другу, и им также нужно постепенно находить общий язык с членами своей семьи, чтобы уменьшить количество конфликтов.

\section{2. Конфликт культуры питания}

Диета - это самая основная потребность человека и потребность самого низкого уровня для удовлетворения физиологических потребностей людей. Диета является основой человеческого существования. После удовлетворения основных потребностей потребности людей в питании будут постепенно увеличиваться. На пищевые привычки различных регионов влияют историческое наследие, географическая среда, демографический статус и религиозные влияния. Культуры питания Китая и России уникальны и привлекательны, но когда эти две привычки переплетаются, различия в культуре питания порождают конфликты. Прежде всего, это проявляется в разных вкусах еды. Большинство китайцев в России - 
северяне, в то время как северная кухня в основном тушеная, соусная и жареная. Китайские блюда отличаются ярко выраженным вкусом, разнообразием приправ, при этом русская еда не так вкусна, как китайская, имеет более легкий вкус. Во-вторых, это проявляется в разных способах питания. Для россиян хлеб и чай обязательно должны присутствовать на столе во время еды. Россияне склонны употреблять алкогольную продукцию. В дополнение к обычным приемам пищи они предпочитают полдник. Постоянная привычка есть заставляет китайцев чувствовать, что русские тратят много времени на приготовление еды, а русские считают, что китайцы просто не наслаждаются жизнью. Кроме того, русские предпочитают вино, но для китайцев вино - это только форма общения, а алкогольное поведение проявляется только за обеденным столом. Для китайско-российских трансграничных браков это также может стать причиной конфликта.

\section{3. Конфликт образовательных процессов}

Образование всегда было серьезной проблемой и важной задачей в Китае. Что касается образования детей, то китайские родители обычно считают, что образование детей должно начинаться в раннем возрасте. Поэтому они используют методики раннего развития детей. Этот метод соответствует свободному мышлению. Русские родители стараются не навязывать своим детям дополнительное обучение, за исключением обычного школьного обучения и интереса детей к учебе.

Поэтому в межгосударственных браках между Китаем и Россией, когда образовательная идеология, основанная на самовыражении, вступает в противоречие с интенсивным обучением, возникают разногласия относительно концепции обучения и способа воспитания ребенка. В традиционной китайской семье существует четкое разделение труда между мужчинами и женщинами, и женщины должны нести ответственность за все семейные дела, включая воспитание детей. Когда они сталкиваются с китайско-российской транснациональной брачной семьей, то ответственность на воспитании детей ложится на женщину. В образовательной концепции русских женщин развитие личности детей - нормальное явление, и больше внимания уделяется воспитанию детской самостоятельности, что неизбежно приведет к конфликтам, вызванным культурными различиями.

Китайско-российский транснациональный брак это процесс культурной адаптации. Можно сказать, что счастливые транснациональные браки возникают изза успешной культурной адаптации, в то время как неудачные транснациональные браки возникают из-за неудавшейся культурной адаптации. Обычно считается, что культурная адаптация имеет два аспекта: психологическая адаптация и социокультурная адаптация. Межкультурная адаптация в основном включает изменения в поведении и психологии людей, которые имеют межкультурный контакт, а культурная интеграция в основном включает изменения в познании, отношениях и ценностях. В процессе китайско-российского транснационального брака первая стадия - сладкая. В этот период, из-за взаимного предпочтения двух сторон, культурные различия также будут ощущаться меньше, поскольку супруги недавно вступили в брак. По мере увеличения времени, проведенного вместе, неизбежно возникнут конфликты. Этот период является испытанием для обеих сторон в китайско-российских транснациональных браках, и они получат более глубокое понимание друг друга. Если вы хорошо понимаете и адаптируетесь друг к другу в этот период, конфликты могут разрешиться, и счастливый брак продолжится. Если этого не произойдет, случится неминуемый развод.

\section{Зак^ючение}

С развитием глобализации и углублением китайскороссийских дружеских отношений китайско-российские транснациональные браки становятся все более распространенными. Но вкус подобен человеку, пьющему воду, зная, что она холодная или теплая. С одной стороны, китайские и российские транснациональные браки хотят непредвзято принимать красивых невест или красивых женихов из стран с культурными различиями. С другой стороны, они естественным образом отвергают те части, которые слишком противоречат их собственной культуре. В этом романтическом и противоречивом процессе обе стороны должны уважать культурное разнообразие, понимать и терпимо относиться друг к другу, и тогда будет счастливый транснациональный брак. Счастливые международные браки часто требуют больше терпения, понимания и внимания.

Хотя культурные конфликты между этническими группами распространены повсеместно, большинство китайско-российских транснациональных браков являются стабильными и хорошими. С развитием Интернета, туризма и обучения за рубежом, а также с постепенным открытием китайской концепции транснационального брака и любви, обмены между людей Китая и России станут еще больше. Близкие и глубокие люди будут выбирать транснациональные браки более тщательно и рационально, а сила любви будет способствовать взаимной интеграции культур двух стран, так что качество транснациональных браков браки будут становиться все выше и выше. 


\section{ЛИТЕРАТУРА}

1. Дин, Лин. Межкультурная коммуникация - о культурном конфликте в транснациональных браках / Лин Дин // Библиотека знаний - 2019. - № 12. C. 154-159.

2. Ли, Кэ. Обзор китайско-российских транснациональных браков: на примере Ланьчжоу / Кэ Ли // Естественнонаучное 0бразование. - 2009 - № 27. C. 132-136.

3. Лукин, А.В., Иванов, А.В. Российско-китайские отношения: проблемы и перспективы / А.В. Лукин, А.В. Иванов // Вестник МГИМ0 университета. - № 3. C. 312-317.

4. Gudykunst, W.B. An Anxiety/Uncertainty Management (AUM) Theory of Strangers'Intercultural Adjustment / W. B. Gudykunst // Theorizing about intercultural communication. - 2005. - Pp. 419-457.

5. Triandis, Harry S. Individualism and collectivism / Harry S. Triandis: New Directions in Social Psychology. - 1995. - 250 p.

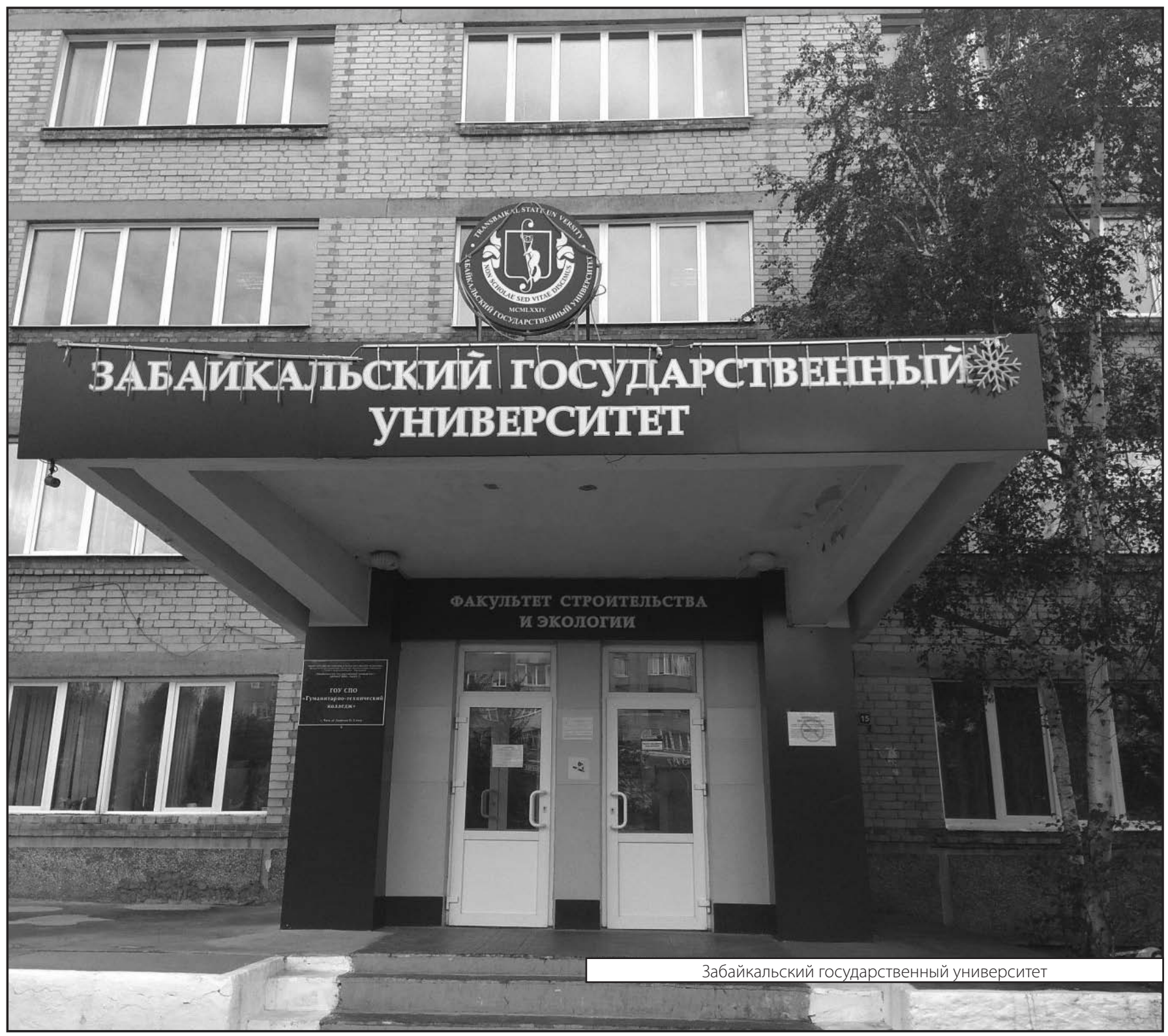

